\title{
HYDROGEOLOGY OF THE MISSISSIPPIAN SCARP-SLOPE KARST SYSTEM, POWELL MOUNTAIN, VIRGINIA
}

\author{
Benjamin Schwartz ${ }^{1}$ and William OrndorfF²
}

\begin{abstract}
Mississippian carbonates on scarp-slopes of Powell Valley show few surficial karst features, yet host extensive caves (e.g., Omega, Hairy Hole, Rocky Hollow, and Gap Caves) and complex karst hydrogeologic systems. On the limbs of the Powell Valley Anticline, strata dip moderately to steeply into the mountainside, with passage development and flow dominantly along the strike toward water gaps, nickpoints, or structures such as fold axes or faults. Most significant cave development is in the Greenbrier Limestone, which is underlain by Price-Maccrady Formation siliciclastics and overlain by shales, siltstones, and minor limestones of the Bluefield Formation (including the approximately $13-\mathrm{m}$ Little Lime, approximately $100 \mathrm{~m}$ above the Greenbrier Limestone). The South Fork of the Powell River, flowing northwest through Powell Mountain at Crackers Neck water gap, defines local base level in the area of recent hydrogeologic studies. Dye traces northeast of Crackers Neck revealed that allogenic recharge sinks into the Little Lime limestone layer and flows southwest beneath the river, resurging on the southwestern bank at the Little Lime Spring. High-flow conditions overwhelm the input capacity of the Little Lime outcrops, and water continues down-slope to sink in the Greenbrier Limestone, then flows southwest along the strike through dominantly vadose cave passages in Omega Cave to the Omega Spring on the northeast side of the Powell River. The stream in Omega Cave is undersized, suggesting that most passage enlargement occurs during high-flow events. Inflows in the upper Greenbrier Limestone near the Crackers Neck water gap drain to a spring on the opposite side of the Powell River. Northeast of the Omega basin, flow is to the northwest, resurging at the nose of the Powell Valley anticline. Springs on the southwest bank of the Powell River receive flow from karstic drainage to both the northeast and southwest, as well as from the river itself. At Powell River Spring, river water includes upstream discharge from Little Lime Spring. This situation resulted in confusing dyerecovery patterns before Little Lime Spring was discovered.
\end{abstract}

DOI: $10.4311 /$ jcks $2008 \mathrm{es} 0036$

\section{INTRODUCTION}

The Mississippian carbonates exposed in southwestern Virginia have long been known to contain significant caves (Douglas, 1964; Holsinger, 1975). Well-known examples include the Cudjos-Cumberland Gap Cave System in Lee County and many other caves along the Powell Mountain and Stone Mountain escarpments in Lee, Scott and Wise Counties. Several of these were extensively mined for saltpetre (Douglas, 1964; Faust, 1964; Holsinger, 1975). Except for interest in the saltpetre caves and intermittent periods of exploration in a few new caves, there has been little systematic or prolonged exploration and study of caves in the region, and even less scientific study of the hydrogeology of karst systems developed in the Mississippian karst of this region. Reasons for this range from the relative inaccessibility of the karst exposures high on steep mountainsides to attention being focused, instead, on other well-known karst regions in Virginia.

However, the early 1990s brought renewed interest in this area when exploration in caves near East Stone Gap in Wise County revealed that many known caves were incompletely mapped and that many unknown caves existed. By the mid-1990s, a historically known blowing pit had been pushed beyond a blocked passage at the base of the entrance shaft to reveal the first pieces of a large and extensive cave system consisting of active and paleo passages. Named the Omega Cave System, it is now both the longest $(40.5 \mathrm{~km})$ and deepest $(385 \mathrm{~m})$ cave system in the state, and new passages are still being discovered.

Coinciding with the initial exploration and mapping of the Omega Cave System and other caves in the area, was the initiation of hydrogeologic studies in the Mississippian carbonate scarp-slope karst system that contains the cave system. These studies are the first to establish the hydrogeologic significance of the Mississippian scarp-slope system and to determine the relationship between karst systems developed in the Greenbrier Limestone and a stratigraphically higher, but thin, limestone known locally

\footnotetext{
${ }^{1}$ Department of Biology, Texas State University - San Marcos, 601 University Drive, San Marcos, TX 78666 bs37@txstate.edu

${ }^{2}$ Virginia Natural Heritage Program, 8 Radford Street, Christiansburg, VA 24073 Wil.Orndorff@dcr.virginia.gov
} 
as the Little Lime, previously assumed to be hydrologically insignificant.

\section{SCARP-SLOPE KARSTIFICATION}

In this paper, we present a conceptual model and definition of a scarp-slope karst system. This style of karst has largely been ignored or unrecognized in the literature. We believe it is sufficiently different from other styles of karst that it deserves a new descriptive classification. In brief, a scarp-slope karst system develops in soluble rocks dipping into the mountain side, where the region of major conduit development has occurred internal to the scarp face and may be entirely covered or protected by an overlying mountaintop composed of erosionally resistant, ridge-forming lithologies such as sandstone. Regional structural controls halt down-dip development near the regional base level, and water then flows in a master conduit roughly along the strike toward either springs at water gaps or major fractures that transport water across the strike. In the Mississippian-age carbonates of the Powell Valley, springs are always along the strike because of the insoluble and impermeable nature of the underlying formations. In rocks in other areas, such as the CambroOrdovician-age carbonates, springs can be either along the strike or along fractures at high angles to the strike, if underlying formations have appropriate permeability/ solubility characteristics. These Cambro-Ordovician systems, while they are similar to the scarp-slope karst described here, will not be discussed further here and will instead be presented in a separate manuscript.

\section{Study Area}

Stratigraphically, Mississippian carbonates in Wise, Scott, and Lee Counties in southwest Virginia are composed of the $>130$-m-thick Greenbrier Limestone (also known as the Newman Limestone and locally known as the Big Lime) and the approximately 13-m-thick Little Lime in the overlying Bluefield Formation (Henika, 1988). Below the Greenbrier Limestone, lies impermeable shale and sandstone of the locally undivided Mississippian Price-Maccrady Formations. Separating the two carbonates are approximately $60 \mathrm{~m}$ of thinly bedded shales and thin siltstones, sandstones, and mudstones of the Bluefield Formation. Above the Little Lime is an additional $75 \mathrm{~m}$ of Bluefield lithologies, capped at the mountain ridgelines by approximately $50 \mathrm{~m}$ of the erosionally resistant Stony Gap Sandstone member of the Mississippian-age Hinton Formation. The Stony Gap member is a cliff former and creates low but prominent cliff lines along many of the ridge-tops.

Structurally, the carbonates are found exposed on steep scarp-slopes along both limbs of the Powell Valley Anticline. The Virginia portion extends nearly $100 \mathrm{~km}$ from near Norton, where the northeastern end plunges and forms the head of the Powell Valley, to Cumberland Gap at the far southwestern tip of Virginia in Lee County (Commonwealth of Virginia, 2003). The breached and deeply eroded core of the anticline forms Powell Valley, and, incidentally, is the only location in Virginia where Mississippian, DevonianSilurian, and Cambro-Ordovician carbonates are exposed by the same structure, which continues to the southwest beyond the Virginia-Tennessee border. Most of the eastern limb of the Powell Valley anticline is not preserved due to regional thrust-faulting and erosion. However, in southern Wise County and western Scott County, the eastern limb remains and is known as Powell Mountain. Powell Mountain contains dramatic outcrops of the Greenbrier Limestone in the form of cliffs several kilometers in length, up to 80-mhigh, and 300 to $500 \mathrm{~m}$ above the valley floor. The regional dip of the western limb is 30 to 60 degrees to the northwest, while dip angles on the eastern limb are a shallower 5 to 20 degrees to the southeast. It is in this eastern limb near the town of East Stone Gap that the Omega Cave System has formed in the Greenbrier Limestone. On scarp-slopes, outcrops of the Little Lime are commonly covered by Bluefield and Stony Gap colluvium and can be difficult to identify. In steep hollows and water gaps (near Crackers Neck, for example), the Little Lime does form short cliff lines, though overall surface expression is considerably less than the Greenbrier Limestone.

While the exposures of the carbonate units discussed here are regionally extensive, our research to date has been focused on a detailed understanding the hydrogeology of the eastern limb of the Powell Valley Anticline, or the Powell Mountain block, roughly between the towns of Norton and Duffield, Virginia (Fig. 1). Structurally and stratigraphically, our study area is similar to the extensive western limb of the Powell Valley Anticline, with the main difference being the steeper dip of identical strata on the western limb.

\section{Hydrogeology}

Regional and local geologic structures and stratigraphy have controlled the development of all major caves known in these scarp-slope Mississippian carbonates. Regionally, cave systems are formed along fractures sub-parallel to the strike on the limbs of the Powell Valley Anticline. Because strata dip into the mountainsides and the base of the Greenbrier Limestone rests on the insoluble and impermeable Price-Maccrady Formation, water perches on the insoluble strata and is forced to follow an along-strike flowpath to the most efficient discharge point. Locally, water gaps and deeply incised hollows or valleys formed by structural flexures and fracture or minor fault zones perpendicular to the strike control the hydrogeology. In turn, these features provide the discharge points for the regional conduit flow through the carbonates and contain all major springs within the Greenbrier Limestone.

On the surface, there is relatively little indication that a regionally extensive active karst system exists beneath these 


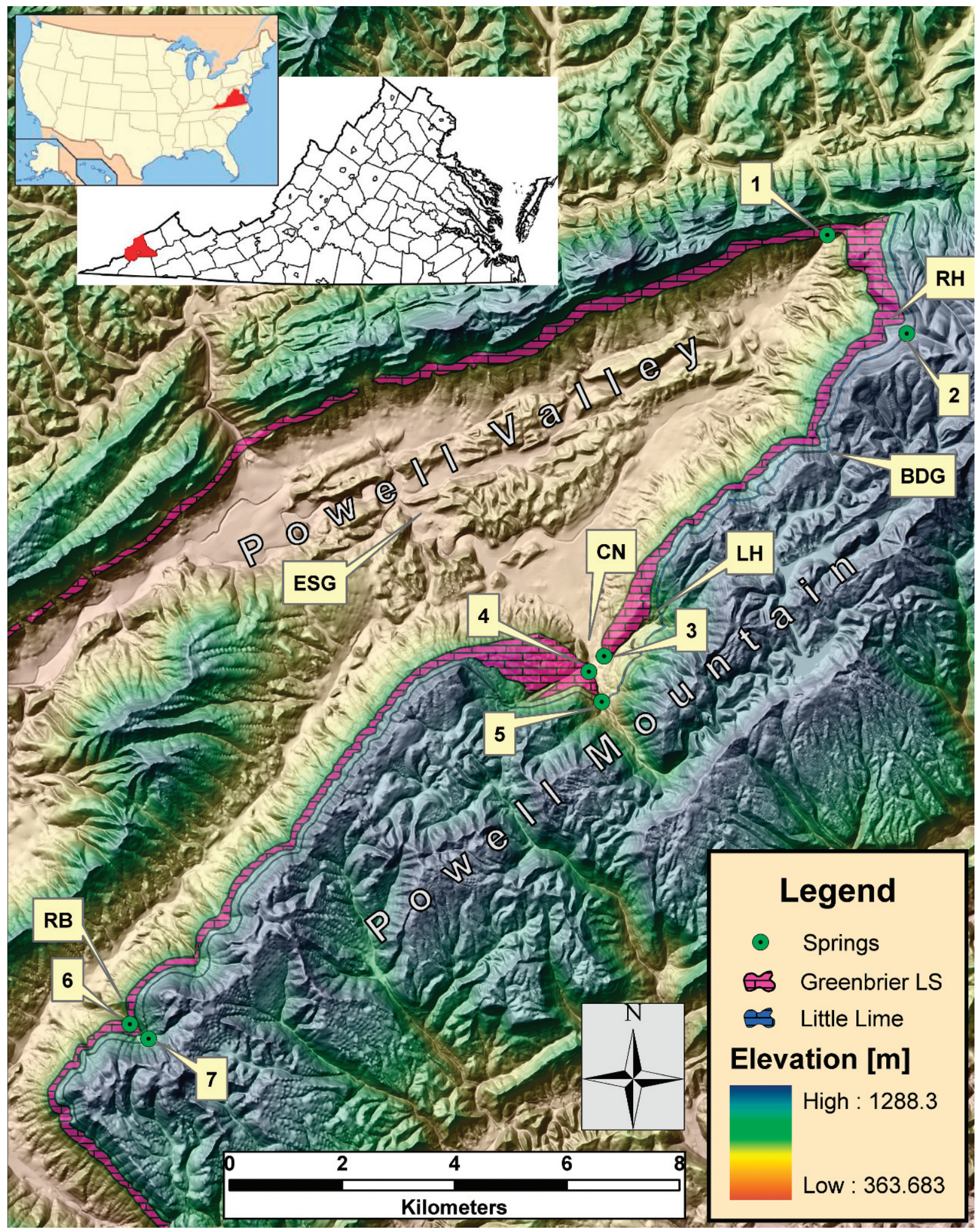

Figure 1. Location, topography (USGS, 2008), Greenbrier Limestone outcrop (USFS, 2008) and Little Lime outcrop of the northeastern Powell Valley and Powell Mountain. Springs are: 1) Bloomer Spring, 2) unnamed Little Lime spring in Rocky Hollow, 3) Omega Spring, 4) Powell River Spring, 5) Little Lime Spring, 6) unnamed Greenbrier spring in Roaring Branch, 7) un-named Little Lime Spring in Roaring Branch. Locations mentioned in text are: $\mathrm{CN}=$ Crackers Neck, ESG = East Stone Gap, BDG = Beaverdam Gap, RH = Rocky Hollow, LH = Long Hollow and RB = Roaring Branch. The South Fork of the Powell River flows to the northwest between 3) and 4) and through the community of Crackers Neck. Two minor gaps between Crackers Neck and Beaverdam Gap are (from north to south) locally known as Sheep Gap and Maple Gap. 
impressive scarp-slope exposures. With few exceptions, development of karst features such as large sinkholes and sinking streams is very limited, though they are quite common in other nearby carbonates. Due to Greenbrier Limestone outcrops being high on steep scarp-slopes below narrow ridgelines, allogenic contributing areas are narrow $(<1 \mathrm{~km}$ wide) and long $(>10 \mathrm{~km})$. With few sink-points or perennial surface streams present above the upper Greenbrier Limestone contact, it might seem that runoff from the mountainsides would simply cascade over the steep cliff exposures without a chance to enter the subsurface. However, except for during large storms, the opposite is true, and much of the overland flow from higher on the mountain actually does enter well-developed karst systems through small recharge features that are frequently buried beneath sediment and colluvium.

In contrast to the few, small karst features on the surface, the Omega Cave System contains an impressively complex and well-developed network of active and fossil conduits. Sequentially abandoned conduits indicate that this system has existed with similar hydrologic inputs for an unknown but extended period of time. Of the four major infeeding streams that join the master stream trunk, three are related to the three known entrances, Blowing, Lori Cori Canyon Cave, and Stingweed. The fourth probably drains Maple Gap, though the source has yet to be determined. Infeeders begin as complex networks of coalescing small tributaries in passages perched on thin, resistant beds within the uppermost 50 to $60 \mathrm{~m}$ of the Greenbrier. These infeeders then descend rapidly to the base of the limestone via shaft complexes and short sections of meandering canyons and crawls. The most important shaft complexes have formed along fracture zones that are related to small erosional hollows or surface gaps along Powell Mountain - Sheep Gap, Beaverdam Gap and Rocky Hollow, for example. Ancient infeeder complexes produced now-abandoned passages that were also hydrologically related to gaps on the surface.

Soon after the discovery of the master conduit in the Omega System, dye-trace studies were initiated to characterize the current hydrologic system. Using standard fluorescent dye-tracing techniques, studies began in 1997 and continued until 2005. As part of the initial study, a spring inventory was performed and several springs issuing from the Greenbrier Limestone were located.

\section{Springs IN THE GREenbrier Limestone}

Of the Greenbrier Limestone springs identified (Fig. 1), the Omega Spring is the smallest and appears to be undersized relative to both the internal passage sizes and the large allogenic drainage area that was initially associated with the cave system. With an estimated mean flow between 0.01 and $0.05 \mathrm{~m}^{3} \mathrm{~s}^{-1}$, it discharges from boulders near the base of the limestone at the toe of a ridge on the northeastern side of Crackers Neck.
Powell River Spring rises from a water-filled conduit near the base of the limestone on the southwestern side of the South Fork of the Powell River in Crackers Neck. Compared to Omega Spring, this spring is quite large. However, much of its flow is derived from the South Fork of the Powell River itself. During normal summer flow conditions, the entire river sinks where it crosses the upper contact with the limestone, resulting in approximately $500 \mathrm{~m}$ of dry riverbed between the inflow and Powell River Spring. Estimated mean flow is between 0.1 and $0.3 \mathrm{~m}^{3} \mathrm{~s}^{-1}$.

Bloomer Spring has an estimated mean flow of between 0.1 and $0.3 \mathrm{~m}^{3} \mathrm{~s}^{-1}$ and discharges from a fault-controlled cave entrance near the base of the limestone at the northeastern end of Powell Valley where the axis of the Powell Valley Anticline plunges to the northeast. An unnamed spring in the Greenbrier Limestone was also located in Roaring Branch several kilometers to the southeast of Crackers Neck.

\section{Springs IN THE Little Lime}

A second spring inventory later identified several other springs that discharge from the Little Lime (Fig. 1). Little Lime Spring was found along the Powell River upstream from the sink point of the Powell River as it crosses the upper contact of the Greenbrier Limestone. As with the Powell River Spring, Little Lime Spring's discharge also appears to be composed primarily of flow from the Powell River, as it partially sinks in its bed approximately $50 \mathrm{~m}$ upstream from this small cave-entrance resurgence. Mean discharge is estimated to be between 0.1 and $0.3 \mathrm{~m}^{3} \mathrm{~s}^{-1}$.

Two other unnamed springs in the Little Lime are relatively large (between 0.1 and $0.3 \mathrm{~m}^{3} \mathrm{~s}^{-1}$ ) and, unlike the Greenbrier Springs, discharge at high elevations in major hollows (Rocky Hollow and Roaring Branch) from perched karst-aquifer systems on the eastern limb of the Powell Valley Anticline. Discharge from both of these springs flows a short distance across the intervening Bluefield Formation before sinking at the upper contact of the Greenbrier Limestone.

\section{Dye Trace Results and Discussion}

\section{Omega System and Associated Little Lime}

Fluorescein dye was released in the main stream in the Omega Cave System near the downstream end of the system (Fig. 2). This dye was detected only at Omega Spring. Although the exact travel time is unknown $(<2$ weeks between exchange of charcoal traps), the dye probably took less than 24 hours to travel the approximately $1 \mathrm{~km}$ between the release point and the spring. This trace proved what had been assumed when the stream was discovered: that the stream observed in the cave discharges from the Omega Spring down-gradient and along the strike.

In an effort to delineate the upstream end of the hydrologic system, a second tracer was injected on the 


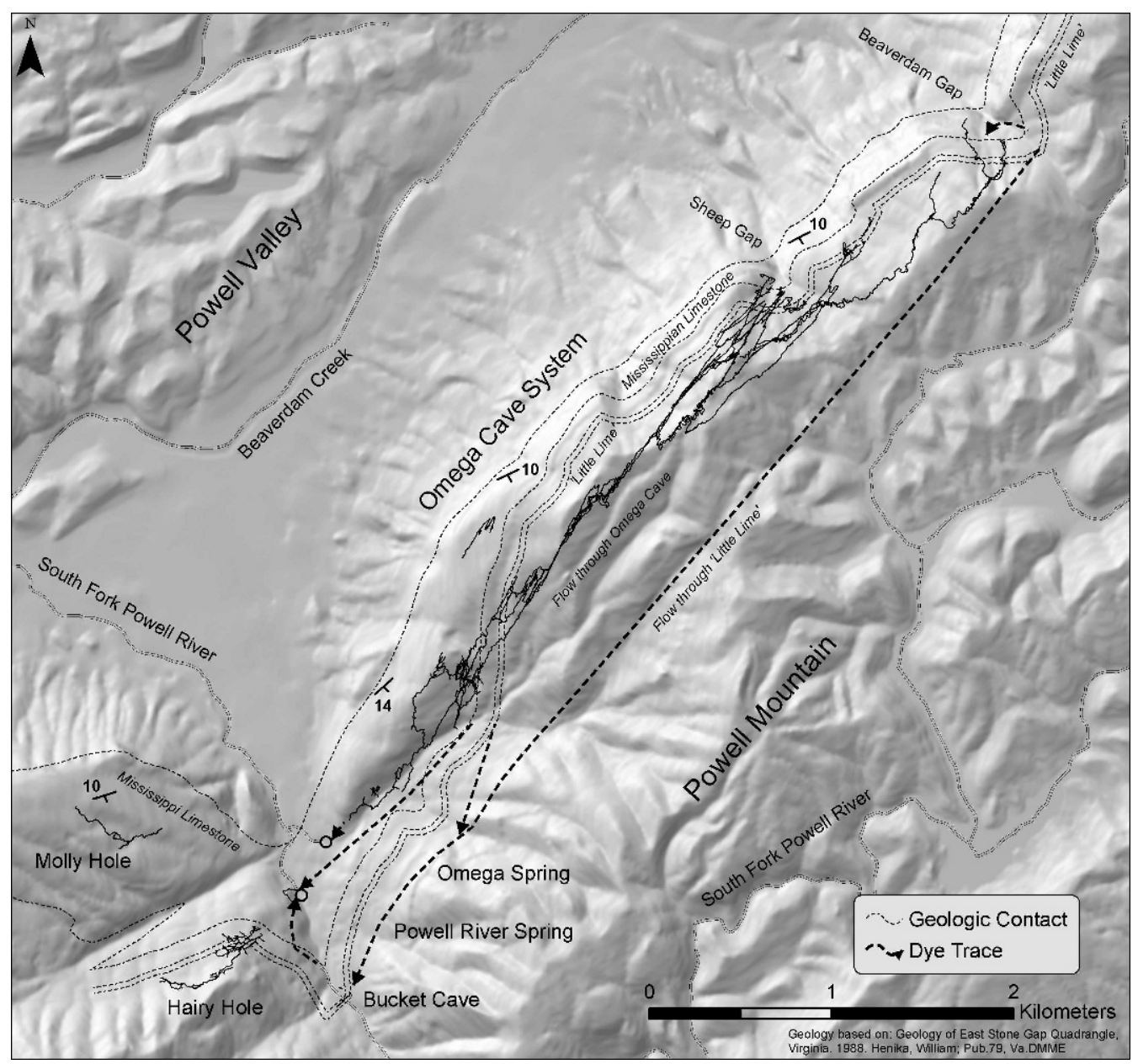

Figure 2. Portion of Figure 1 showing details of the Omega Cave System and other nearby caves. Known flow-paths are noted and dye-trace vectors are shown as dashed lines between injection points and detection points. Approximate surface exposures of the Greenbrier Limestone and Little Lime are shown in dashed outline.

surface in Beaverdam Gap, beyond the northeastern extent of the cave system at that time. Here, a very small perennial surface stream was presumed to sink through gravel and into the Greenbrier limestone. Surprisingly, dye from this trace was detected in very low concentrations at the Omega Spring and much higher concentrations at Powell River Spring.

Because this trace occurred prior to the discovery of the Little Lime springs, only the Greenbrier Springs had been monitored. To explain the unexpected results, two hypotheses were put forth: 1) Two parallel conduit systems exist in the Greenbrier Limestone, one leading to the Omega Spring and the second leading to Powell River Spring. 2) A significant conduit system exists in the Little Lime that is capable of transmitting water to a previously undetected spring up-river from the known Powell River sink point. To test these possibilities, more field work was performed, and Little Lime Spring was found. Merely the existence of this spring proved that some sort of a karst system could develop in the Little Lime, but without knowing the proportion of cave-derived vs. river-derived water, its extent and signifi- cance were difficult to predict. With the newly discovered spring being monitored, the Beaverdam Gap trace was repeated. Most of the dye from the repeat trace was detected at Little Lime Spring, where it then flowed down the South Fork of the Powell River to the Greenbrier sink point and flowed underground to reach the Powell River Spring, the location where most dye had been detected during the previous trace. During the repeat trace, a small amount of dye was again detected at the Omega Spring.

The reason both traces resulted in a low dye concentration at the Omega Spring is apparently related to overland flow after small thunderstorms and the fact that dye was injected upstream of the Little Lime contact rather than just above the Greenbrier Limestone. Just after the injection, most dye quickly entered the Little Lime system. Small storms mobilized some of the remaining dye and transported it down-gradient to the upper contact with the Greenbrier Limestone. The limited capacity of the Little Lime to receive water by infiltration through streambed sediments here is easily overwhelmed, and some runoff 
from storms will flow overland until it sinks at the upper contact with the Greenbrier Limestone and travels through the Omega System. In essence, both dye traces proved two important points: a significant karst system does exist in the Little Lime, and the hydrologic extent of the Omega System extends at least as far as Beaverdam Gap. If the dye had been injected at the Greenbrier Limestone contact as was initially intended, the Little Lime might still be unrecognized as hosting a significant karst system. Since these traces, two caves and a promising dig site have been discovered in the Little Lime. The dig and one of these caves have impressive airflow, indicating that significant air-filled passages do exist in the Little Lime.

In Crackers Neck, a small community near the downstream end of the Omega System, the karst hydrology is more complex. This is the result of the two parallel but hydrologically separate carbonate units, as well as the alongstrike dissection of surface drainage on the Greenbrier Limestone outcrop in Long Hollow. Long Hollow extends to the northeast from the Omega Spring and is deeply incised into the upper portions of the Greenbrier Limestone.

Dye injected in a small tributary stream in Long Hollow at the upper contact with the Little Lime proved that during normal summer flow conditions most allogenic water draining from the mountainside is captured by the Little Lime karst system and flows to the Little Lime Spring on the southwestern side of Powell River. During higher flow conditions at this site, some surface water crosses the Little Lime and flows down to the upper contact of the Greenbrier Limestone. In a subsequent trace in the same tributary, dye injected at the upper Greenbrier Limestone contact was recovered at the Powell River Spring, also on the southwest side of Powell River. This trace proved the existence of an adjacent drainage basin in the Greenbrier Limestone near the downstream end of the Omega System. This had been hypothesized because of the fact that much larger amounts of water were observed sinking here than were discharging from the Omega Spring and the fact that no related infeeding streams are observed in the downstream section of the Omega System. Interestingly, water sinking in Long Hollow discharges on the opposite side of the Powell River, proving once again that surface streams often do not represent hydrologic boundaries in karst systems.

Between the sink and rise of the South Fork of the Powell River, additional water is added via conduits draining adjacent basins. The Long Hollow drainage basin has been proven by dye trace to join this underground segment of the river. Additional flow is also derived from Hairy Hole Cave (currently approximately $3 \mathrm{~km}$ ) on the southwest side of the Powell River. A passage in the cave can be followed until it joins a short air-filled segment of passage containing the underground Powell River. Diving has also proven the connection between Powell River Spring and Hairy Hole Cave. According to survey data and personal communication with diver Ron Simmons, all the underwater passage surveyed in Powell River Spring has developed at depths of between 0 and $10 \mathrm{~m}$.

Well-developed karstic flow systems in the Little Lime on both sides of Powell River drain to the Little Lime Spring on the southwest side of the river. On the northwest side of the Powell River, water that sinks as far to the northeast as Beaverdam Gap has been traced to this spring. Dye travel times $(<2 \mathrm{wk}$ to travel $6 \mathrm{~km})$ and several blowholes in the Little Lime suggest that a well-developed conduit system has developed in this unit. On the southwest side of Powell River, no dye traces have proven the existence of an extensive karst system in the Little Lime. However, Bucket Cave, which is the only significant cave currently known in the Little Lime (approximately $300 \mathrm{~m}$ in length), extends to the southwest from near Little Lime Spring and acts as a flood-water overflow route for water that is presumably flowing from the southwest toward the spring. The existence of a flood-water overflow route is further evidence that the Little Lime system is well-developed and captures large amounts of allogenic water at certain times.

\section{Rocky HoLlow}

Rocky Hollow lies adjacent to and northeast of Beaverdam Gap and the Omega System drainage. The largest known cave in this area is Rocky Hollow Cave $(1.7 \mathrm{~km})$, which is largely an inactive fossil remnant of a much older system. Dye traces in a sinking stream in Rocky Hollow and in Rocky Hollow Cave have proven that water that sinks in the Greenbrier limestone flows to Bloomer Spring at the head of the Powell Valley. Interestingly, much of the water that sinks into the Greenbrier in Rocky Hollow has been discharged from a perched Little Lime spring higher in this deeply incised hollow. Due to the absence of surface streams or other recharge features where dye can be injected, the exact location of the drainage divide between the Omega Spring/ Powell River Spring and the Bloomer Spring drainage basins has not yet been determined. And there is no reason to assume that the boundary for the overlying Little Lime system will correspond to that of the Greenbrier.

\section{ROARING BRANCH}

Preliminary field observations indicate that the relationships between the Little Lime and Greenbrier appear to be similar in both Rocky Hollow and Roaring Branch. Although no dye-traces have been performed in Roaring Branch, a large perched Little Lime spring discharges high in the hollow. This water then flows down to the Greenbrier contact, where it sinks and likely contributes to discharge from the un-named spring near the base of the Greenbrier limestone in Roaring Branch.

\section{Speleogenesis of the Omega System}

The extensive network of passages explored and mapped in the Omega Cave System (currently $40.5 \mathrm{~km}$ ) provides an

Journal of Cave and Karst Studies, December 2009•173 


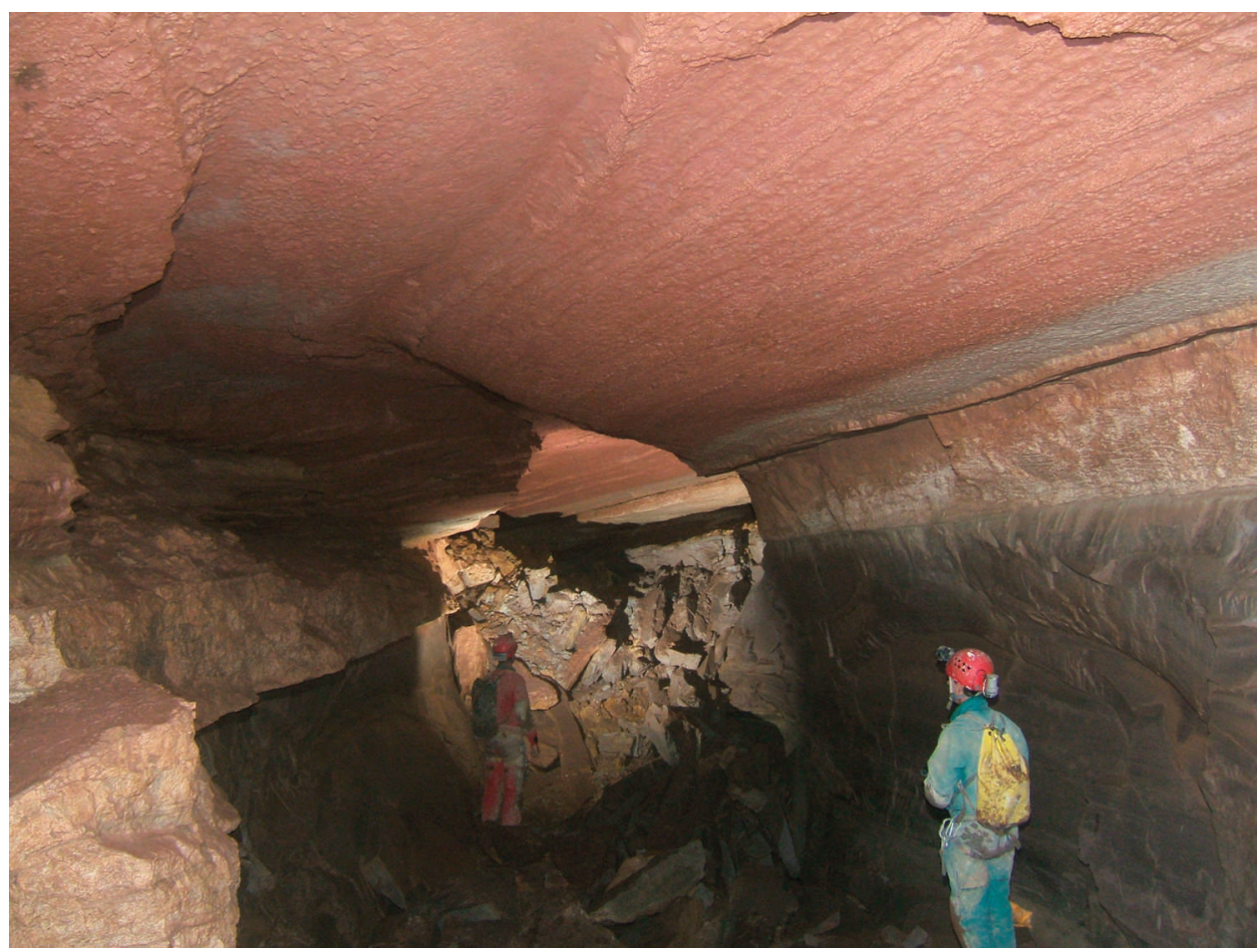

Figure 3. An upper-level passage in which the upper half has formed in a massively bedded maroon red-bed and the lower half has formed in a massively bedded purple red-bed. Note the approximately $60-\mathrm{cm}$-thick limestone bed separating the two lithologies. Also note the meandering ceiling channel that formed under phreatic conditions. The lower half of the passage has been so severely modified by spalling breakdown that it is impossible to tell how it formed, though there appears to be a narrow vadose canyon below that is nearly filled with breakdown debris.

opportunity to observe features and processes that are related to current and past hydrologic conditions. An observation that was initially quite puzzling is that the active master conduit appears to be significantly larger than would be expected to develop from the very small stream running through it. This was partially resolved when the importance of the Little Lime and its role in capturing allogenic recharge before it reached the Greenbrier Limestone was recognized and understood. However, this only explained the small size of the stream and not the oversized passage. The oversized passage appears to be the result of large amounts of chemically and physically aggressive flood waters periodically pulsing through the system. Observational evidence indicates that flow through the master conduit varies by perhaps as much as four orders of magnitude. Low-flow during dry summer conditions has been measured at approximately $0.0015 \mathrm{~m}^{3} \mathrm{~s}^{-1}$, while flood-water discharge likely reaches $1.5 \mathrm{~m}^{3} \mathrm{~s}^{-1}$ or more. This flood discharge estimate is based on high-water marks after rain events.

Passage development in the Omega Cave System is controlled by a combination of structural features (primarily joints) and lithologic variations. In the upper half of the limestone, several massive to shaly-bedded argillaceous carbonate red-beds influenced the vertical development of multiple stacked fossil passages. The influence of these beds on passage development varies significantly depending on location. In some passages, a red-bed unit acted as an aquitard that perched the passage for long distances, while other passages developed entirely within the red-bed (Fig. 3). Reasons for this are not yet fully understood. In the downstream half of the known cave, the main stream passage is resting directly on the underlying PriceMaccrady Formation. In the upstream half of the system, the active stream is perched on sequentially higher redbeds, with approximately horizontal segments of canyon passage separated by waterfalls. Waterfalls are the locations of active nick-point migration as the more dissolutionally-resistant red-beds dissolve more slowly than the purer limestones between them.

The dominant passage morphology in the system is vadose canyons formed along a joint set approximately $15^{\circ}$ south of the southwest strike direction. Many portions of the cave also show evidence of shallow phreatic conditions and vadose-modified phreatic passage (Figs. 4 and 5). These areas are generally associated with certain combinations of structural or stratigraphic controls that created localized shallow-phreatic conditions, or are found at the ceiling level in multi-level canyon complexes where the uppermost passage began as a water-filled conduit at or near the local water table. There is little evidence for deep-seated phreatic development in the Omega Cave System, and the system's evolution generally follows a model of sequential abandon- 


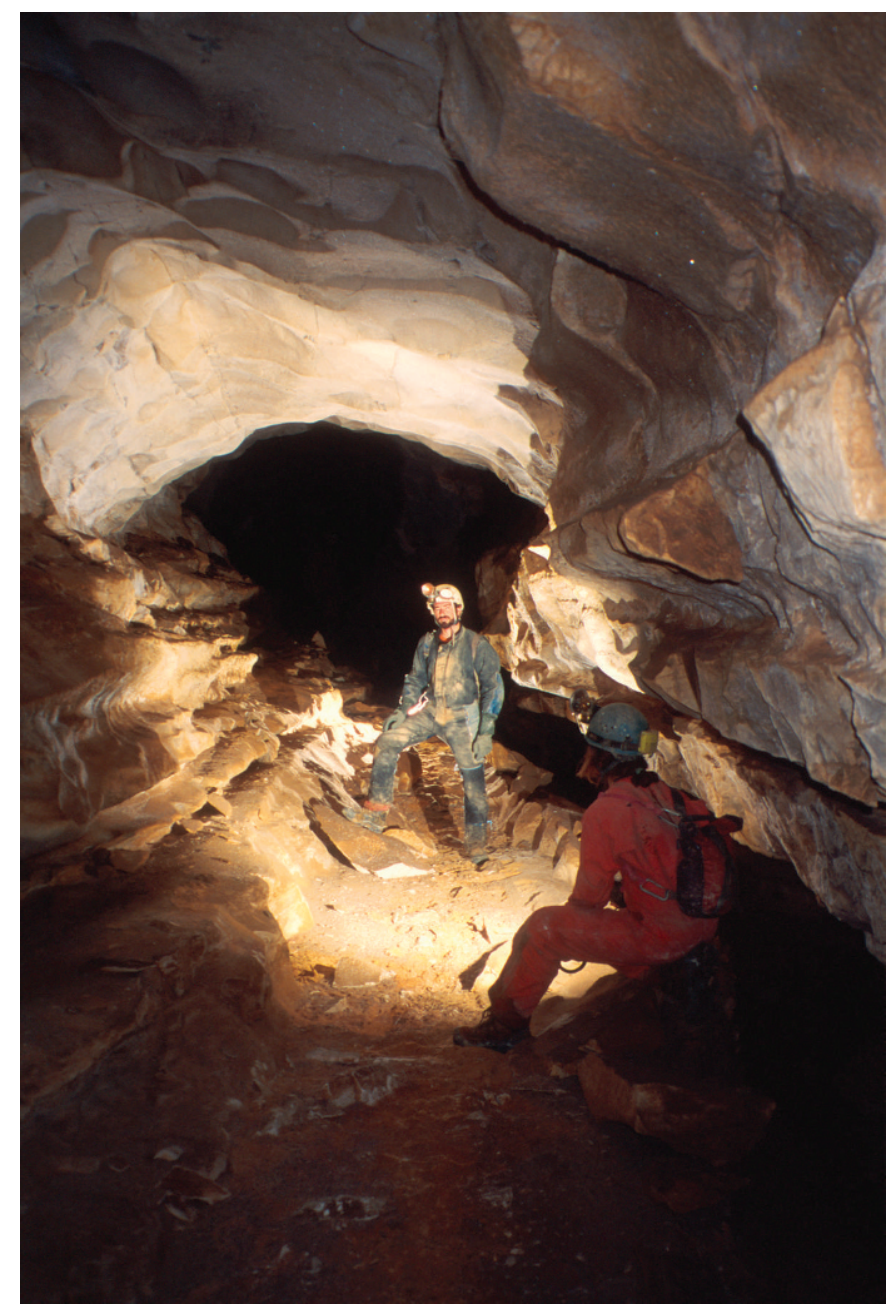

Figure 4. The ceiling level of a passage in Omega that initially formed under phreatic conditions (note large scallops on the ceiling), then transitioned into a partially water-filled passage (wall notches mark the level of slow-moving pooled water), and finally turned into a low-gradient, meandering vadose canyon that is still active today (the canyon portion is under the right wall in this view and drops approximately $30 \mathrm{~m})$.

ment and down-cutting toward a regional base-level that has been lowered over time by landscape evolution and erosion. However, some of the fossil or relict caves (including many of the saltpeter caves, for example) preserve features and morphologies indicative of phreatic conditions and flow. At least one cave, nearby Parsons Cave, may be a fossil resurgence, based on its morphology as a single large tube ascending obliquely updip near, but over $200 \mathrm{~m}$ above, the modern water gap at Crackers Neck.

\section{Paleo-Flow and the Age of Caves in the System}

Although research is currently underway to more completely understand the speleogenetic history of the area, the paleo-hydrologic conditions and landscape

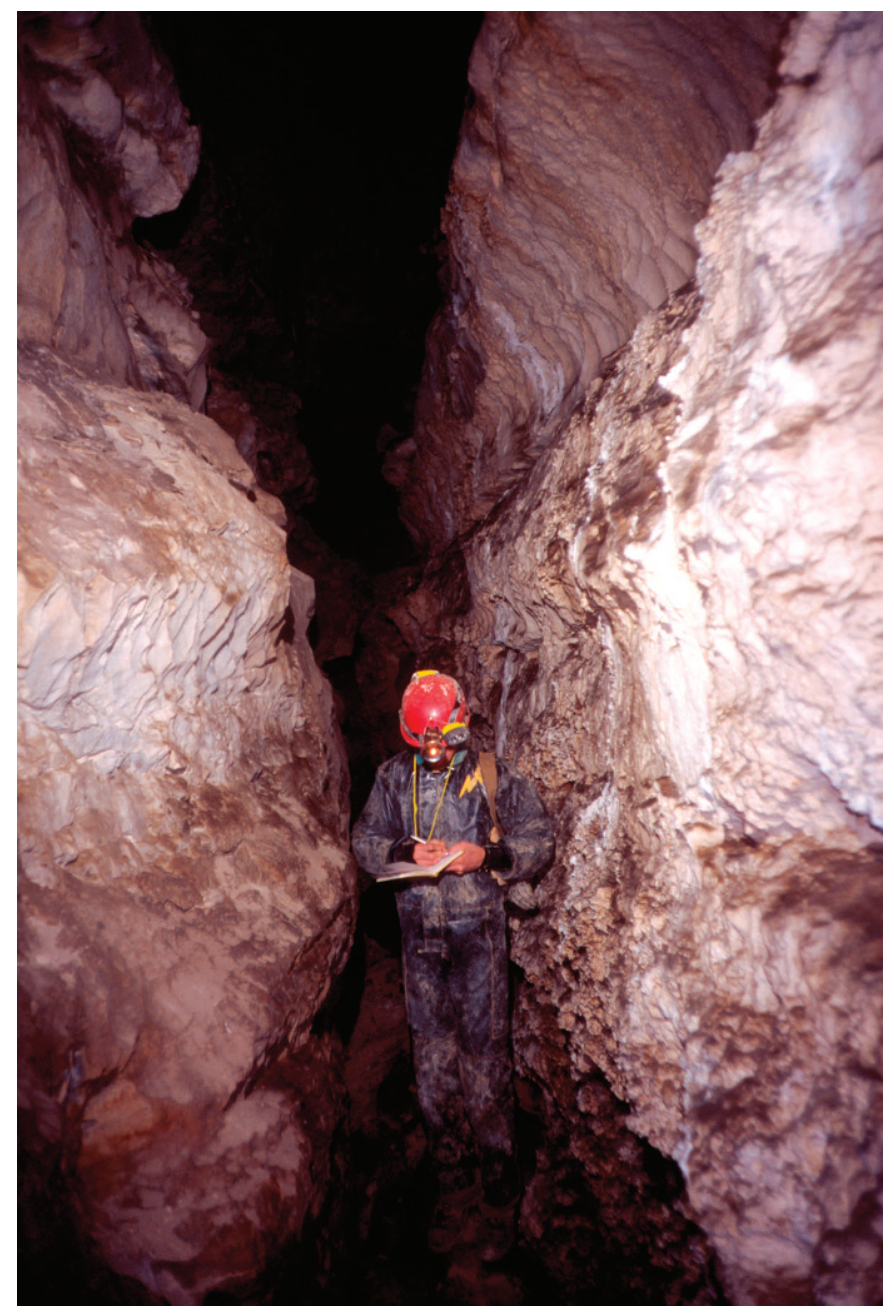

Figure 5. Abandoned vadose canyon passage typical of the Omega Cave System. Passage height in the photo is approximately $15 \mathrm{~m}$.

associated with the relict caves, and how the relict and active caves are related, we can reach some general conclusions about flow and landscape evolution based on our current knowledge and understanding of the system.

With the exception of Parsons Cave (Fig. 6), all observed paleo-flow directions in the Omega System are similar to the present flow direction, i.e., generally to the southeast. While it is very close to, and even overlaps passages in Omega, there is currently no evidence indicating that Parsons Cave has any hydrologic or genetic relationship to the modern Omega System. In fact, ceiling features in Parsons Cave indicate that flow was in the opposite direction, to the north-northeast, and the cave likely represents a paleo-resurgence that discharged water from a much older karst system that is now largely eroded away. Regardless of the flow direction, Parsons Cave was formed under phreatic conditions (Fig. 7), and this fact allows us to make a simple calculation as to the approximate minimum age of karstification in the region. 


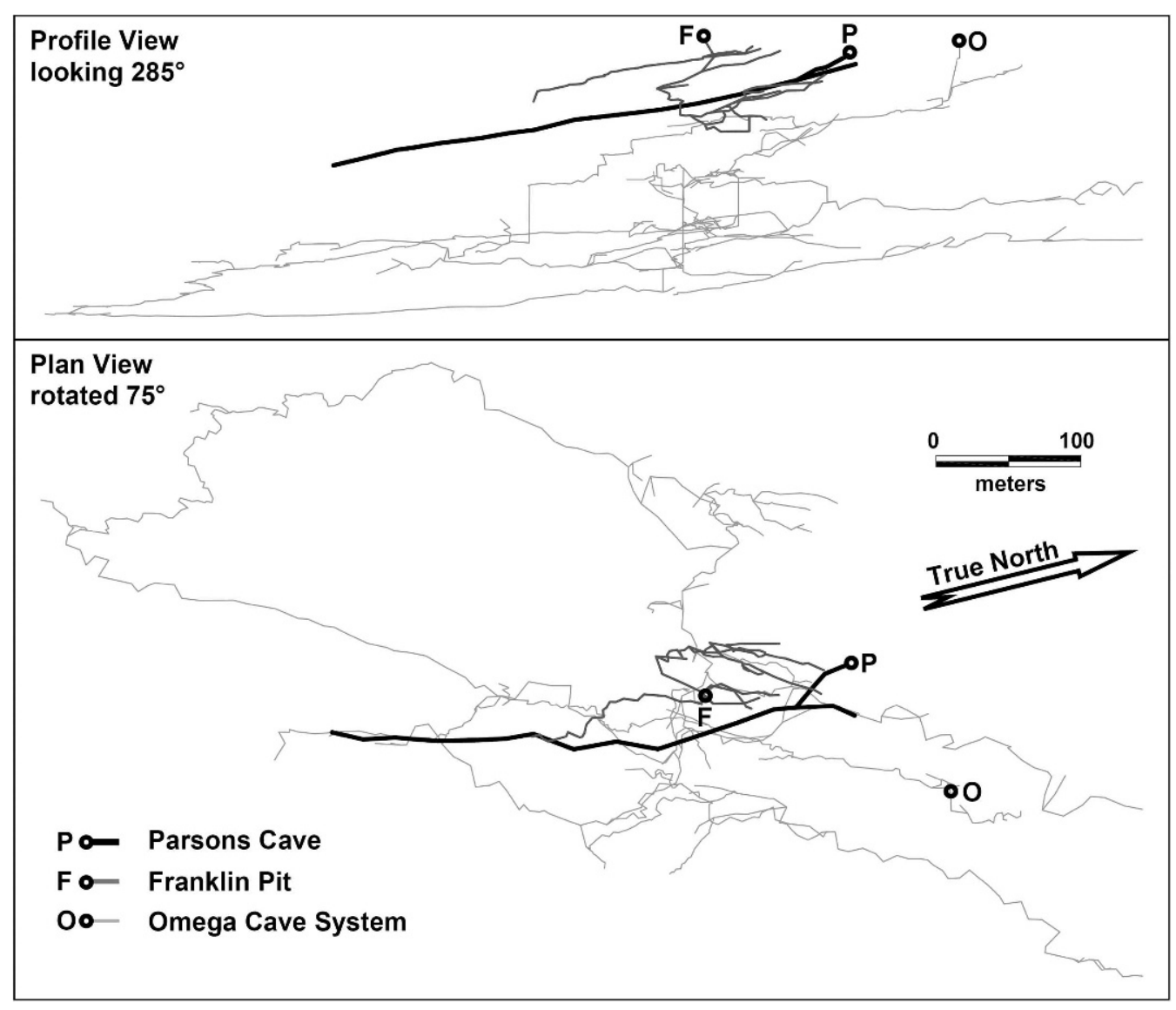

Figure 6. The relationship between Parsons Cave (single bold black survey), Franklin Pit (medium width gray survey) and a portion of the underlying Omega Cave (thin gray survey) near the downstream end of the system (see Figure 2 for complete line plot). Scale is identical in plan and profile views, with no vertical exaggeration. Note that the three caves do not connect.

The entrance to Parsons Cave is currently $200 \mathrm{~m}$ higher than the Omega Spring and opens into a single descending trunk passage $400 \mathrm{~m}$ in length and 90 -m-deep that terminates at a flowstone pinch. If we assume a regional incision rate of approximately $30 \mathrm{~m} \mathrm{Ma}^{-1}$ (Granger et al., 1997; Ward et al., 2005) and assume that the land surface around the cave entrance has not been eroded (only for the purposes of calculating a minimum age), this means that the entrance of Parsons Cave is evidence of a welldeveloped, but water-filled, karst system that existed between 6 and 7 Ma. Omega Spring and Powell River Spring are both at similar elevations of approximately $525 \mathrm{~m}$ asl, which is approximately $30 \mathrm{~m}$ higher than the average elevation of the river bottom in the center of Powell Valley. Unless the stream channel has changed its profile configuration considerably, it is also reasonable to assume that the center of Powell Valley has also been eroded by a minimum of $200 \mathrm{~m}$ since the time when Parsons Cave was still in phreatic conditions.

If Parsons Cave actually is a paleo-resurgence, this may indicate a difference between the modern and ancient systems: deeper circulation of water in the past than in the present. There is no evidence of deep phreatic flow in any of the paleo passages currently known in Omega Cave. In fact, all evidence points toward short segments of shallowphreatic or near-water-table flow that later transitioned into vadose conditions. Deep circulation today is limited to moving farther under the mountain in the down-dip direction by insoluble rock beneath the limestone. This could imply that rates of incision at the surface have varied considerably over time and Parsons Cave represents development during a relatively stable period when deep flowpaths had time to develop. Or Parsons Cave could be the remains of a system with an entirely different hydrologic function than hypothesized here.

Near Parsons Cave lies Franklin Pit (Fig. 6), yet another relict cave. While it appears to be significantly older than the Omega System, there is also no known relationship with Parsons Cave. At this time, very little is understood about the formation and significance of Franklin Pit with respect to speleogenesis in the area, and more work is being done to understand this.

Although more work is needed before the evolution of karst in this system can be considered well understood, none of our observations conflict with the general scarpslope karstification model that follows. 


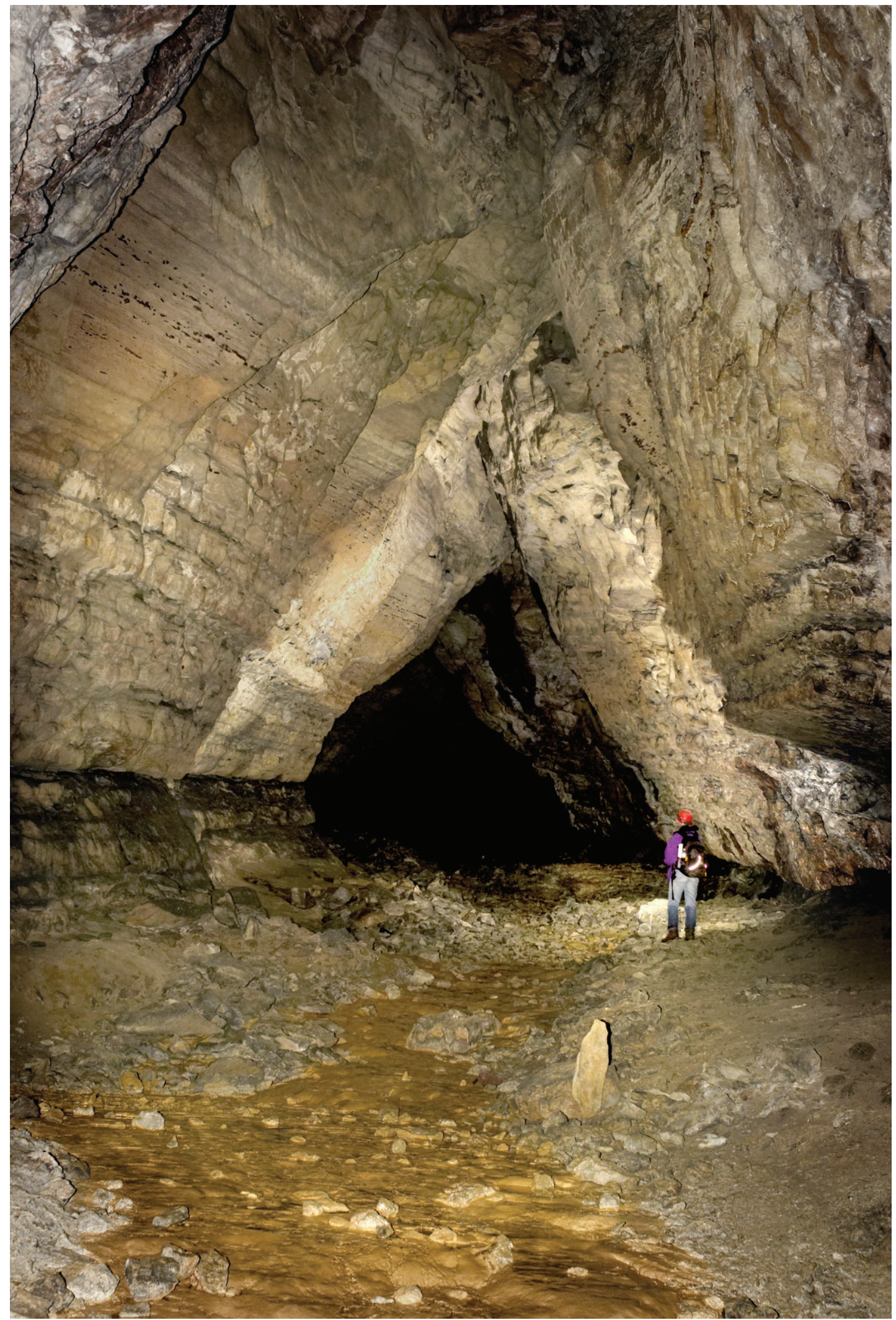

Figure 7. Passage in Parsons Cave as viewed looking toward the entrance. Note that the passage appears to have formed along the intersection of a joint and a prominent bedding plane. Ceiling features indicative of upward flow are not obvious in this picture. Breakdown has modified the walls in many areas, and the floor has been modified by saltpetre mining. The tancolored strip down the center of the passage is a thin coating of modern flowstone. 


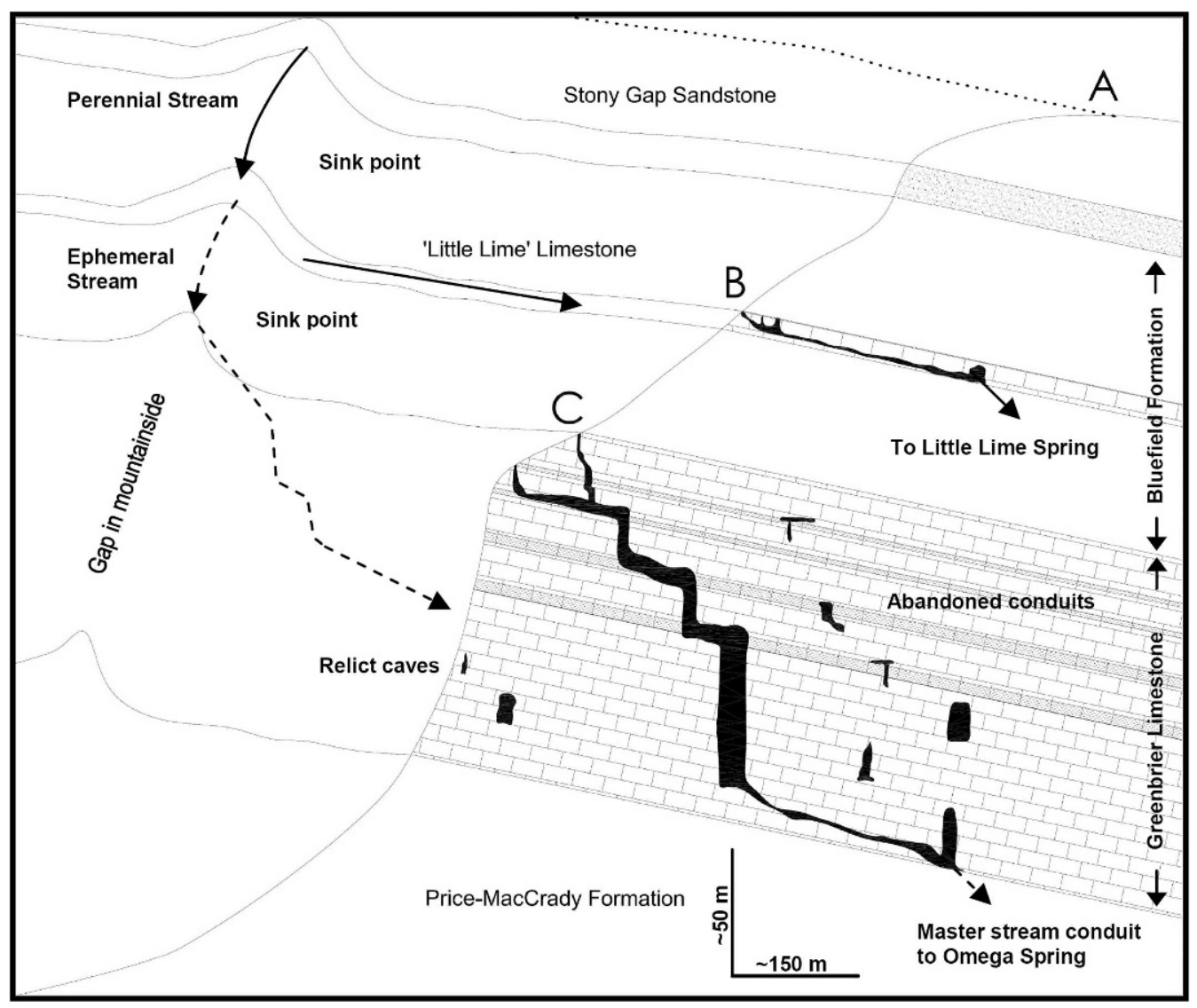

Figure 8. Cut-away conceptual model of Mississippian scarp-slope karst system that generally reflects conditions found near the Omega Cave System A) is the crest of Powell Mountain B) marks a hypothetical entrance passage in the Little Lime that leads down-dip to the Little Lime master stream conduit. Note that the Little Lime system has not been entered by cavers, while the Greenbrier system has $\mathbf{C}$ ) is a simplified representation of an entrance to the Omega Cave System and a passage that leads to the Greenbrier master stream trunk. Note that the location and thickness of red-beds in the upper half of the Greenbrier are for schematic purposes only and are not precisely represented. Vertical exaggeration is approximately 3:1.

\section{Conceptual Model of Mississippian Scarp-Slope KARST HyDROLOGY}

This research resulted in the development of a conceptual model for a scarp-slope karst system (Fig. 8). From a hydrogeologic perspective, the most important components of the general scarp-slope model are: 1) Soluble rocks are exposed on a scarp-slope below a ridge of resistant ridge-forming insoluble rocks. 2) Soluble rocks dip into the overlying mountainside. 3) Allogenic recharge flows off the insoluble ridge and sinks at or near the upper limestone contact before flowing generally down-dip toward a strike-oriented main stream passage deep within and behind the scarp-slope. 4) Water flows along the strike toward a spring in a water gap or deep hollow in the ridge, or toward a major fracture zone where flow crosses the structure and underlying rocks of lower solubility (dolostones, for example) to discharge at a valley-bottom spring. 5) A significant to dominant portion of the water flowing through the system is allogenically derived. 6) Major cave streams are largely undersaturated with respect to calcite, and thus capable of significant dissolution. 7) Steep slopes above the limestone contact result in extremely flashy systems capable of significant physical weathering by abrasive clasts in the sediment load.

The general model can be refined and specifically applied to the Central Appalachian Mississippian scarp-slope system by adding the following essential elements: 1) The stratigraphically higher Little Lime karst system captures most allogenic recharge during normal hydrologic conditions. 2) Excess surface drainage or discharge from high-elevation Little Lime springs crosses the intervening Bluefield Formation and enters the Greenbrier Limestone. 3) The base of the karst system in the Greenbrier Limestone is defined by the contact with the underlying Price-Maccrady Formation, which forces all Central Appalachian Mississippian scarpslope springs to be along-strike. 4) Significant across-dip flow only occurs in major water gaps where sinking streams enter at the upper contact and discharge from a spring at the lower contact along the same stream channel.

Both the Little Lime and the Greenbrier Limestone systems direct subsurface flow long distances along the 
strike via well-developed conduit systems toward a regional discharge point formed at structurally controlled water gaps or deeply incised hollows. Both systems can be thought of as gutters at different elevations on the scarpslopes, with varying capacities for allogenic recharge. Based on discharge, high-elevation Little Lime springs likely have extensive conduit development associated with them, though there is currently little direct evidence, such as mapped cave passages.

With sediment cover and narrow exposures limiting rapid recharge via sinking streams or sinkholes into the Little Lime, the Greenbrier Limestone system is activated during high-flow events that flush chemically and physically aggressive waters through the system. This results in an over-sized conduit. When large or intense storms occur, significant amounts of water bypass both the Little Lime and Greenbrier Limestone and reach the floor of Powell Valley as runoff. No perennial streams cross the scarpslope carbonate exposures and reach the valley bottom.

Passage morphologies in the Omega Cave System suggest that most development currently occurs during large floods, with major inputs occurring primarily in only a few poorly developed gaps or hollows. This is supported by observations in the cave, where three of the four feeder streams to the main stream trunk are associated with an obvious gap on the surface.

\section{Conclusions}

This first thorough hydrogeologic investigation of a Central Appalachian Mississippian scarp-slope karst system has shown that both the Greenbrier Limestone and the thin Little Lime can form well-developed karst systems. In all cases documented, water discharging from the Little Lime almost immediately sinks in the Greenbrier Limestone just down-slope and contributes significantly to discharge from certain Greenbrier Limestone springs. Omega Spring, which receives no hydrologic input from a Little Lime spring, appears undersized in relation to the amount of allogenic recharge available from the slope above the Greenbrier Limestone. Instead, recharge into the Little Lime overlying the Omega Cave System is directed to the Little Lime Spring, where it then contributes to discharge from Powell River Spring. During normal flow conditions, the Little Lime captures nearly all allogenic recharge from higher scarp-slopes. During storm events, the low capacity of the Little Lime recharge zones is easily overwhelmed, and excess flow will recharge the Greenbrier Limestone system directly, as well as contribute to surface runoff into Powell Valley.

Conduit development in the Omega Cave System is dominated by sequential down-cutting and abandonment over time, resulting in a complex network of stacked strikeoriented passages. Modern enlargement of the active master stream passage appears to be dominated by chemically and physically aggressive flood water that enters via narrow canyon passages connected by active shafts. During normal flow conditions or summer drought, discharge from the Omega Spring nearly stops. This is due to a combination of factors, including a narrow surface exposure of the Greenbrier Limestone and the overlying Little Lime system capturing the majority of allogenic recharge during periods with little precipitation.

This research has resulted in a general conceptual model of Mississippian scarp-slope karst hydrogeology that provides a framework for future research in the area. We have also proposed that scarp-slope karst systems develop in a unique manner with unique properties and should be recognized as a category of karst that is common in the folded and faulted sedimentary rocks of the Appalachian Mountains.

\section{ACKNOWLEDGMENTS}

Dye-trace analyses were performed by Nevin W. Davis and the Virginia Natural Heritage Program. We thank Stan Allison, Bill Balfour, Mike Ficco, Andrea Futrell, Jim Kennedy, Jerry Fant, and Tommy Shifflett for field assistance during the dye traces. We also acknowledge the contributions of the cavers involved in this project who have worked together during thirteen years of exploration and documentation of the Omega Cave System. It is important to remember that cave exploration and speleology are intimately related. Photos used in Figures 3 and 5 courtesy of Mike Ficco and the photo used in Figure 7 courtesy of Art and Peg Palmer.

\section{REFERENCES}

Commonwealth of Virginia, 2003, Digital Representation of the 1993 Geologic Map of Virginia, Publication 174: Richmond, Department of Mines, Minerals and Energy, Division of Mineral Resources, Compact Disc.

Douglas, H.H., 1964, Caves of Virginia: Falls Church, Va., Virginia Cave Survey, $761 \mathrm{p}$.

Faust, B., 1964, Saltpeter caves and Virginia History: in Douglas, H.H., ed., Caves of Virginia: Falls Church, Va., Virginia Cave Survey, p. $31-56$.

Granger, D.E., Kirchner, J.W., and Finkel, R.C., 1997, Quaternary downcutting rate of the New River, Virginia, measured from differential decay of cosmogenic ${ }^{26} \mathrm{Al}$ and ${ }^{10} \mathrm{Be}$ in cave-deposited alluvium: Geology, v. 25, no. 2, p. 107-110.

Henika, W.S., 1988, Geology of the Virginia Portion of the East Stone Gap Quadrangle, Virginia, Virginia Division of Mineral Resources, scale $1: 24,000,2$ sheets.

Holsinger, J.H., 1975, Descriptions of Virginia Caves: Richmond, Virginia Division of Mineral Resources Bulletin 85, $450 \mathrm{p}$.

United States Forest Service, 2008, GIS data homepage, http://www.fs. fed.us/r8/gwj/general_info/gis_data.shtml] [accessed December 8, 2008].

United States Geological Survey, 2008, The National Map Seamles Server, http://seamless.usgs.gov/ [accessed December 8, 2008].

Ward, D.J., Spotila, J.A., Hancock, G.S., and Galbraith, J.M., 2005, New constraints on the late Cenozoic incision history of the New River, Virginia: Geomorphology, v. 72, p. 54-72. 